\title{
Notch signaling in glioblastoma: a developmental drug target?
}

Maria Maddalena Lino ${ }^{1}$, Adrian Merlo ${ }^{1 * \dagger}$, Jean-Louis Boulay ${ }^{1,2+}$

\begin{abstract}
Malignant gliomas are among the most devastating tumors for which conventional therapies have not significantly improved patient outcome. Despite advances in imaging, surgery, chemotherapy and radiotherapy, survival is still less than 2 years from diagnosis and more targeted therapies are urgently needed. Notch signaling is central to the normal and neoplastic development of the central nervous system, playing important roles in proliferation, differentiation, apoptosis and cancer stem cell regulation. Notch is also involved in the regulation response to hypoxia and angiogenesis, which are typical tumor and more specifically glioblastoma multiforme (GBM) features. Targeting Notch signaling is therefore a promising strategy for developing future therapies for the treatment of GBM. In this review we give an overview of the mechanisms of Notch signaling, its networking pathways in gliomas, and discuss its potential for designing novel therapeutic approaches.
\end{abstract}

\section{Introduction}

Gliomas are defined as brain tumors of glial origin. Based on histology, gliomas have been classified into astrocytoma (70\%), oligodendroglioma (10\% to $30 \%)$, mixed oligoastrocytoma and ependymoma $(<10 \%)$. Lowgrade gliomas, mostly astrocytomas (World Health Organization (WHO) grade II) are progressively transforming into malignant gliomas, that is, anaplastic tumors (WHO grade III) and ultimately into glioblastoma multiforme (GBM; WHO grade IV). However, most GBM are diagnosed without any prior record of a tumor of lower grade [1,2]. GBM is a complex mixture of cell types that includes astrocyte-like and stem-like cells, characterized by rapid growth and diffuse invasiveness into adjacent brain parenchyma. Resectability depends on tumor location and only the nodular component can be surgically controlled. The infiltrative component of the tumor, however, is left to unspecific and cytotoxic chemotherapy and radiotherapy that can impede tumor progression for a limited time only. GBM patient survival is of less than 1 year $[2,3]$. GBM has a severe mutator phenotype that consists of large chromosomal alterations $[4,5]$. At the genetic level, the most

\footnotetext{
* Correspondence: adrian.merlo@gmx.ch

† Contributed equally

'Laboratory of Molecular Neuro-Oncology, Department of Biomedicine,

University Hospital Basel, Basel, Switzerland

Full list of author information is available at the end of the article
}

frequent mutations affect genes involved in the control of cell cycle, growth, apoptosis, invasion and neovascularization $[6,7]$. In the past few years, it has become apparent that Notch signaling, a major player in normal development of the central nervous system, is often misregulated in GBM. In this review we will focus on the role of Notch in gliomagenesis and discuss potential therapeutic opportunities.

\section{Notch: genetics, biology and signaling Pioneer observations on Notch in Drosophila}

The Notch mutation was discovered by Thomas Morgan in 1917 in the fruit fly Drosophila melanogaster, with an adult phenotype consisting of 'notches' at the wing margin. Genetic analyses of Notch loss-of-function mutations also revealed an embryonic phenotype with an expanded population of neuroblasts at the expense of epidermis cells. These mutations provided the first clue that during neurogenesis, wild-type Notch regulates the cell fate decision by preventing ectoderm cells from differentiating into neuroblasts rather than into epidermis, and have been therefore qualified as neurogenic mutations [8]. Further identification of antineurogenic gainof-function mutations completed the description of the allelic series of Notch $[9,10]$. Both loss-of-function and gain-of-function Notch mutations are dominant in Drosophila, where loss and gain of a single gene copy is sufficient to mimic hypomorphic and hypermorphic 
mutations [9-11]. Thus, the Notch expression level is likely to be critical to ensure the subtle balance between neuroblast and epidermal cell fate decision during Drosophila development.

\section{Cloning of Notch genes}

Cloning of the Drosophila Notch gene [12] revealed a type I transmembrane receptor consisting of 36 epidermal growth factor (EGF)-like tandem repeats and 3 cysteine-rich LIN-12/Notch (LIN) repeats in the extracellular domain. The extracytoplasmic juxtamembrane region forms both $\mathrm{N}$-terminal and $\mathrm{C}$-terminal heterodimerization domains (HD-N and HD-C, respectively). The cytoplasmic part contains an RBPJk-binding (RAM) domain, six tandem ankyrin (ANK) repeats, a transcription activation domain (TAD) and a proline/ glutamate/serine/threonine-rich (PEST) sequence. Post-translational cleavage of the single Notch receptor chain at site S1 located between HD-N and HD-C domains and subsequent heterodimerization between HD-N and HD-C generates a functional receptor $[13,14]$. Notch1 ligands, receptor domains and processing are illustrated in Figure 1. Vertebrate genomes encode four Notch paralogs, where Notch1 and Notch2 show strong structural homology with Drosophila Notch. Notch3 and Notch 4 are more distantly related, with 34 and 29 EGF-like repeats, are and devoid of TAD domains [15-18].

\section{Expression pattern in mammalian brain}

In rodent late embryonic and postnatal brain, Notch1, Notch 2 and Notch 3 transcripts are commonly present in germinal zones, but with distinct patterns and later postembryonic expression of Notch2 [19,20]. In postnatal mouse brain, Notch2 expression persists in glial cells harboring markers of immature phenotype: high vimentin and low glial fibrillary acidic protein (GFAP) [21]. Consistent with expression in immature glial cells in the germinal zones, Notch signaling is required for preventing neuronal differentiation and promoting neural stem cell (NSC) maintenance for further commitment into glial lineage. Maintenance of the NSC population by Notch signaling prefigures a possible role of Notch signaling in the maintenance of glioma stem cell (GSC) population [22-26].

\section{Notch signaling mediators}

In mammals, Notch receptors are activated by five type I transmembrane ligands, three Delta-like (Dll1, Dll3 and Dll4) and two Serrate/Jagged (Jag1 and Jag2) receptors (Figure 1). All contain a cysteine-rich 'Delta, Serrate, Lag' (DSL) motif found in Drosophila respective orthologs Delta and Serrate/Jagged and in Caenorhabditis elegans Lag2. Numbers of EGF repeats vary between

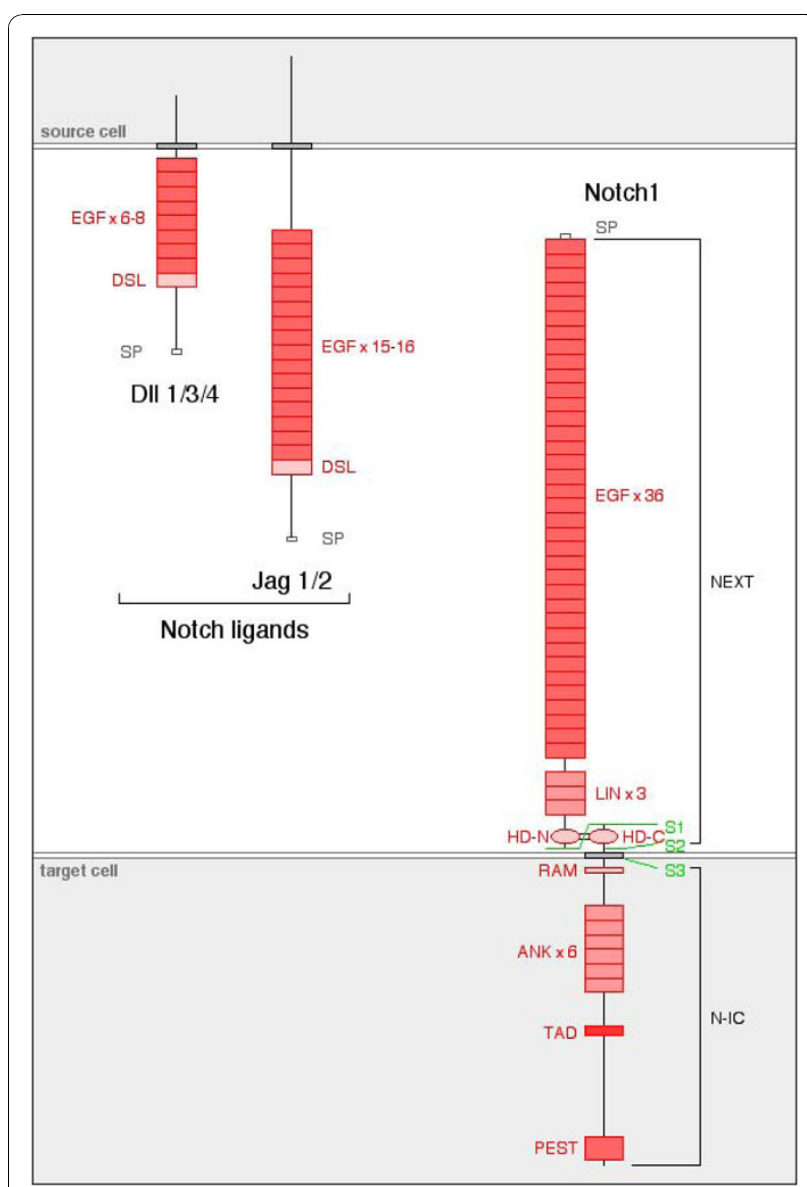

Figure 1 Ligands, structure and processing of Notch1 receptor. Left: the Delta-like ligand (DII) and Serrate-Jagged ligand (Jag) structural subsets of Notch ligands. Right: structure of Notch1 receptor resulting from post-translational cleavage at site S1 and heterodimerization of the cleaved parts. Ligand-dependent cleavages at sites S2 and S3 generate soluble Notch extracellular truncation (NEXT) and cytosolic Notch intracellular domain (N-IC) forms, respectively. Notch1 and Notch2 are highly similar. Notch3 and Notch 4 contain 34 and 29 epidermal growth factor (EGF)-like repeats, and are devoid of trans-activation domain (TAD) domains.

Dll and Jag ligands (6-8 and 15-16, respectively) [27] Recently, epidermal growth factor-like domain 7 (EGFL7) has been identified as a soluble antagonist of Notch signaling [28]. Ligand-dependent cleavage at site S3 within the transmembrane domain (Figure 1) of the membrane-bound receptor releases a Notch intracellular (N-IC) form, which translocates to the nucleus. There, it binds $\mathrm{Su}(\mathrm{H}) / \mathrm{CSL} / \mathrm{CBF} 1 / \mathrm{RBPJk}$ to trans-activate target genes such as the hairy/enhancer of Split HES and $H E Y$ families of basic helix-loop-helix transcription factors $[27,29,30]$. These successive events are dissected in the upper part of Figure 2. An additional ligand-dependent cleavage at extracellular site S2 (Figure 1) leads to the release of a soluble form of Notch named Notch extracellular truncation (NEXT) [31]. 


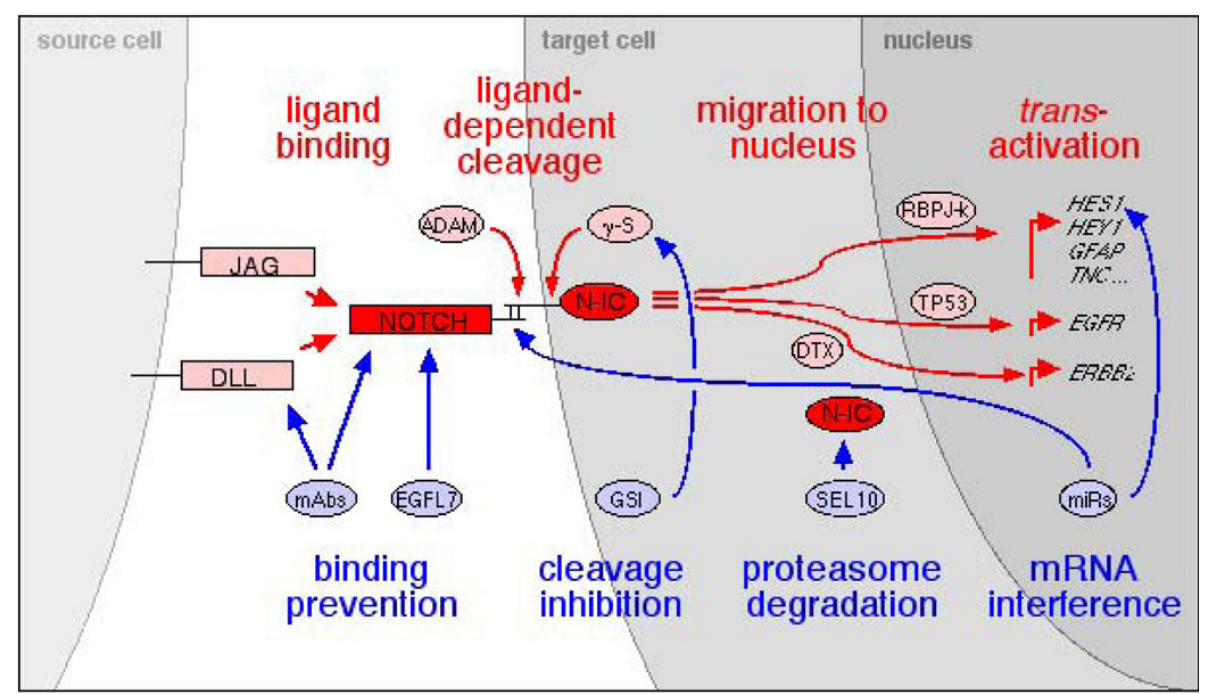

Figure 2 Sequential events and control of Notch signaling. Activating and inhibitory mechanisms are depicted in red and blue, respectively.

Further, a non-canonical RBPJk-independent and Deltex-dependent alternative pathway has been described in humans and in Drosophila [32,33]. Together with this observation, in T helper (Th) cells, Jagged induces Th2 cell differentiation by triggering the RBPJk-dependent canonical pathway, while Delta-like instructs Th1 commitment through a RBPJk-independent alternative pathway, presumably Deltex-dependent [34].

Physical interactions between Notch target gene products HES1 and HEY1 with Stat3 point to crosstalks between Notch and Stat3-activating pathways such as Gp130/Jak2/stat3 and Sonic hedgehog (Shh) $[25,35,36]$. In parallel, Shh is also capable of stimulating HES1 transcription [37]. In addition, $\beta$-catenin has been shown to interact with Notch and RBPJk to induce HES1 transcription, indicating also crosstalk between Wnt and Notch pathways [26]. Levels of crosstalks between Notch and these pathways are discussed in Hansson et al. [38].

\section{Notch germline mutations, human diseases and knockout models}

In humans, Notch mutations have been associated with dominant developmental disorders and diseases that include brain/neurological, cardiovascular and/or kidney defects. Notch1 in aortic valve disease [39]; Notch2 in Alagille syndrome [40]; Notch3 in Cadasil syndrome [41] and possibly Notch4 in schizophrenia [42]. In mice, global Knockouts of Notch1 or Notch 2 are embryonic and perinatal lethals with vascular and kidney defects $[43,44]$. Surprisingly, Notch 3 and Notch4 null mice showed normal development, viability and fertility. Although Notch1/Notch4 double mutants had more severe defects in angiogenic vascular remodeling, there is no evidence of a genetic interaction between Notch1 and Notch3 $[45,46]$. Hemizygosity of Dll4 as well as Jag1 and Rbpjk Knockouts consistently result in embryonic death due to vascular defects [47].

In fact, occurrence of disorders with embryonic or perinatal lethality are likely to mask the involvement of Notch signaling in later developmental or biological events. This includes GBM progression, onset of which occurs in human adults at the mean age of 62 [2]. Nevertheless, the fact that inactivation of Notch signaling results in constant defects in angiogenesis shows its role in vascular morphogenesis and remodeling during embryonic development, and reveals a possible involvement of Notch signaling in tumor neovasculature.

\section{Notch and cancer}

Notch signaling plays a pivotal role in the regulation of many fundamental cellular processes such as proliferation, stem cell maintenance, differentiation during embryonic and adult development and homeostasis of adult self-renewing organs $[27,48]$. Therefore, it is easy to see how perturbation of Notch signaling may often lead to tumorigenesis.

\section{Notch and malignancy}

The first evidence for a role of Notch in tumorigenesis came from the finding that the acute $\mathrm{T}$ cell lymphoblastic leukemia translocation (T-ALL) $t(7 ; 9)(\mathrm{q} 34 ; \mathrm{q} 34.3)$ breakpoint generated the fusion of the gene for the $\beta$ chain of the $\mathrm{T}$ cell receptor at $7 \mathrm{q} 34$ and the TAN1/ NOTCH1 gene at $9 \mathrm{q} 34.3$, giving rise to a constitutively active N-IC-like domain [49]. More generally, acquired gain-of-function Notch mutations in T-ALL cluster at HD domains to form constitutively active receptors, and 
at the PEST domain to stabilize active N-IC [50]. Similarly, a fraction of B cell lymphomas harbor mutations in the PEST domain of Notch2 [51]. Further, Notch proteins have been shown to be involved in tumors of various origins. However, oncogenic or tumor suppressive activities of Notch depends on the cellular context [52] or might be a matter of Notch expression level, as observed in neural stem cells [53]. In other neoplasms, such as non-small cell lung cancer and skin cancer, Notch has a tumor suppressor function [6,7].

As discussed in the next section, Notch signaling is one of the major pathways involved in GBM development. Notch signaling has been shown to maintain proliferation of normal neural precursors and has been defined as a survival marker in gliomas [23-25,54]. Its oncogenic function in gliomas is based on cell proliferation and invasion $[55,56]$. Data on other tumor cell types showing the role of Notch in epithelial-tomesenchymal transition (EMT) in response to hypoxia may be extrapolated to GBM $[57,58]$.

\section{Notch and GBM}

GBM is the most aggressive central nervous system (CNS) tumor, with the poorest clinical prognosis. This tumor consists of cells that are astrocyte-like but with a complex genetic make-up and expression patterns in which the presence of stem-like cells has been proven $[2,3,59]$. Notch2 has been suggested to drive embryonic brain tumor growth, whereas Notch3 has been implicated in choroid plexus tumors [23,60]. In GBM and in medulloblastoma, the frequency and the intensity of Notch2 expression is higher than that of Notch1 [55,61]. As a consequence of local genomic amplifications at the Notch2 locus in both brain tumor types, this may also be linked to the later persistence of Notch2 expression in postnatal mouse brain [21]. In fact, in medulloblastoma, Notch2 is preferentially expressed in proliferating progenitors, while Notch1 in postmitotic differentiated cells [61]. Interestingly, Purow et al. showed that Notch1 regulates transcription of the epidermal growth factor receptor gene $E G F R$, known to be overexpressed or amplified in GBM, through TP53 [62]. Consistently, transcription of Notch signaling mediator genes are significantly overexpressed in the molecular subset of GBM with EGFR amplification [63]. This new link places Notch signaling as an activator of the major GBM pathway and further clarifies the implication of Notch signaling in cancer and development.

In contrast, a minor GBM subset with local haploidy at $1 \mathrm{p} 12$ has been identified and has been associated with better patient prognosis. Reminiscent of the better outcome of oligodendroglioma patients harboring $1 \mathrm{p} /$ $19 q$ loss, the minimal area of loss in GBM and the detection of homozygous deletions in oligodendroglioma converge to the Notch2 gene [54]. This provided an initial clue that subsets of gliomas (even with distinct histologies) with impaired Notch signaling result in slower progression. A single loss-of-function mutation in the RAM domain of Notch2 has been identified in the glioma line Hs683. This mutation has been further shown to impair Notch-mediated trans-activation, and subsequently tenascin-C (TNC)-mediated invasion, as detailed below [55].

\section{Effect on proliferation and apoptosis by Notch modulation in GBM}

Genomic amplification of $E G F R$ is the most frequent genetic alteration occurring in GBM, a fraction of which undergoes a further deletion that generates the constitutively active $v I I I$ variant $[64,65]$. Consistently, EGF is the major proliferation pathway in GBM, mediated by activation of the RAS-RAF-MEK-ERK and the PI3K-AKTmTOR cascades [66]. Interestingly, mTOR has recently been shown to activate Notch signaling in lung and kidney tumor cells through induction of the Stat3/p63/ Jagged signaling cascade [67]. If true in GBM, this potentially creates a positive feedback loop between Notch and EGF signaling. The most frequent GBM subset consists of the association of EGFR amplification together with homozygous deletions at the CDKN2A (cyclin dependent kinase) locus, and mutually exclusive of TP53 mutations [5]. Since Notch has been shown to activate expression of EGFR via TP53 [62], Notch is expected to stimulate the main GBM proliferation pathway. Of note, the gene for the EGFR-related ERBB2 is also trans-activated by Notch, but in a DTX1-dependent manner [68].

Notch pathway inhibition by $\gamma$-secretase inhibitors (GSIs) reduced GSC proliferation and increased apoptosis associated with decreased AKT and Stat3 phosphorylation [69]. Conversely, expression of an active form of Notch2 increased tumor growth and in vivo delivery of GSI consistently blocked tumor growth, and significantly prolonged survival [69]. Taken together, these results open inhibition of Notch signaling as a promising strategy to control GSC growth.

\section{EMT and invasion}

EMT represents the transition through which a benign tumor becomes malignant. Underlying molecular changes lead to decreased cell adhesion and acquisition of tumor invasiveness [70]. Together with transforming growth factor (TGF) $\beta$, the Jag1-Notch pathway activates HEY1 to trigger EMT of epithelial cells of human, murine and canine origins [71]. The Jag1-Notch-Snai2 cascade has also been showed to induce EMT in human breast tumor cell [57]. Unlike these tumors in which invasion results into remote metastases, GBM invade 
adjacent brain tissue. Further studies may validate the same molecular mechanism in GBM local invasion.

TNC, highly expressed in invasive GBM, is an extracellular matrix glycoprotein [72] that induces proliferation and migration of neuronal precursors in embryonic and postnatal mouse brain neurogenic zones [73], and ensures neuronal regeneration in injured adult brain [74]. TNC levels increase during progression of GBM, such that it can be used as a prognostic marker for GBM patient survival [75]. The molecular mechanism through which Notch signaling induces TNC-dependant glioma cell motility is based on the trans-activation of the TNC promoter by Notch-RBPJk [55]. It is noteworthy that a parallel study in childhood ependymomas has shown an association between tumor recurrence and frequent amplification of the 9qter, precisely at the location of both NOTCH1 and TNC genes [76].

\section{Glioma differentiation and stem cells}

In recent years, it had been suggested that within a tumor, only a subset of cells called cancer stem cells (CSCs), are endowed with tumorigenic capacity [77-79]. These cells are self-renewing and multipotent with tumor initiating potential. The alternative hypothesis that transformation and dedifferentiation of more mature brain cells contributes to tumorigenesis may be a parallel pathway towards tumorigenesis [80]. Notch signaling is crucial for the in vivo maintenance of selfrenewing stem cells in varieties of lineages such as neural, but also hematopoietic or mammary [81-83]. Similar to Notch-RBPJk, Stat3 trans-activates GFAP and induces normal neural precursor cells to differentiate into astrocytes in association with HES1, HES5 or HEY1. At the molecular level, HES1 physically interacts with Jak2 and Stat3 to induce Stat3 phosphorylation and relevant activation $[25,35,84]$. Conversely, the association between Notch, RBPJk and $\beta$-catenin maintains the precursor cell status [26].

Notch2 and HES1 have been shown to maintain the granule neuron progenitor cell population and inhibit further neuronal differentiation [23]. Reciprocally, brainderived EGFL7 regulates Notch-dependent proliferation and differentiation of NSC of the subventricular zone into neurons and oligodendrocytes [28]. Further, neuron-induced Jag1-Notch1 signaling upregulates expression of the radial glia marker brain lipid binding protein (BLBP) [68]. In addition, the gene for Nestin, a marker for neural precursors, is trans-activated by Notch signaling [85]. Consistently, in ependymoma cells, the fraction of CD133-positive cells shows significant coexpression of Notch2 and HES1 [72]. This supports a function of Notch signaling in maintaining the GSC population within a tumor. However, Notch signaling has also been shown to trans-activate the gene for GFAP [86] and to drive the differentiation of glial progenitor cells into astrocytes therefore preventing differentiation into oligodendrocytes [87]. This is consistent with the observation that Notch1 and Notch2 are present at high levels in GBM and astrocytoma [55]. These distinct activities suggest multiple roles for Notch signaling in the course of gliomagenesis, in particular in GBM and astrocytoma development, that remain to be dissected. In oligodendrogliomas, Notch 2 is frequently deleted and the corresponding protein is not detectable [54,55].

MicroRNAs (miRNAs) are short single-stranded RNAs that negatively regulate gene activity by targeting mRNAs for cleavage or translational repression [88]. The miRNA miR-199b-5p has been recently identified as a regulator of the Notch pathway by targeting the transcription factor HES1. Its overexpression blocks expression of several CSC genes and decreases the medulloblastoma stem-cell-like (CD133+) subpopulation of cells [89]. Similarly, treatment of ependymoma neurospheres with GSI-IX results in decrease sphere number, size, proliferation and induced cell-surface adhesion [76]. GSI have been proved to significantly reduce radioresistance of glioma stem cells through inhibition of Notch [90].

GSCs represent a critical therapeutic target to control glioma growth and progression. However, the molecular mechanisms that regulate the stem cell pool are poorly understood. The vascular, perinecrotic and hypoxic niches of the tumor constitute a microenvironment that contributes to the regulation of CSC. Hypoxia plays a key role in the regulation of the CSC phenotype through hypoxia inducible factor (HIF)- $2 \alpha$ and subsequent induction of specific CSC signature genes, including mastermind-like protein 3 (Notch pathway), nuclear factor of activated T cells 2 (calcineurin pathway) and aspartate $\beta$-hydroxylase domain-containing protein 2 [91].

MicroRNA-34a (miR-34a) is a transcriptional target of TP53 that is downregulated in GBM and even more in GBM carrying a TP53 mutation, as compared to normal brain. Transient expression of miR-34a in GBM cells strongly inhibited glioma xenograft growth in vivo by targeting c-Met and Notch [92].

\section{Hypoxia and angiogenesis}

GBM possesses a chaotic tumor structure consisting of accumulating tumors cells, abnormal vessel and necrotic debris. The increasing tumor mass leads to pressure gradient leading to capillary and venous collapse [66]. The new formed vessels are structurally and functionally abnormal, and leaky, giving rise to edema, high interstitial fluid pressure and, consecutively, low oxygen tension [93]. In contrast to high $\mathrm{O}_{2}$ tension, which degrades HIF-1 $\alpha$ (hypoxia inducible factor) and promotes 
differentiation or apoptosis of NSCs, lower $\mathrm{O}_{2}$ tension $H I F-1 \alpha$ facilitates signal transduction pathways that promote self-renewal [94]. This hostile microenvironment selects for a more malignant phenotype by clonal outgrowth of hypoxia-resistant tumor cells.

Genetic models have shown the role of Notch in normal arteriogenesis and neoangiogenesis [95]. Its influence is also crucial for neovascularization in cancer contributing to the aggressive clinical behavior of tumors expressing high levels of Notch ligands [96,97]. Recently, Notch1 has been shown to upregulate $H I F-1 \alpha$ expression in breast cancer. In turn, HIF-1 $\alpha$ binds and stabilizes activated Notch to enhance Notch signaling $[73,97,98]$. Thus, $\mathrm{O}_{2}, \mathrm{HIF}$ and Notch regulation may play together a crucial role also to the normal architecture and dynamics of NSC regulation.

\section{Manipulating the Notch network in brain tumors for therapeutic benefit}

Manipulating the Notch pathway would directly and indirectly influence all the downstream and collateral pathways that interact with the complex Notch family signaling.

\section{Notch signaling target genes}

As described above, Notch signaling trans-activates and upregulates genes expressed in gliomas. Canonical Notch/RBPJk-dependence has been shown for GFAP [86], HES1 [87], HEY1 [71], BLBP [99], NESTIN [85], TNC [55] genes while non-canonical DTX1-dependent trans-activation has been shown for ERBB2 [68]. Finally, Notch1 induces TP53-dependent EGFR expression [62]. However, the molecular genetic mechanism of this latter cascade remains to be elucidated. Thus, the oncogenic role attributed to Notch signaling is acting through a complex array of effector genes.

\section{Notch signaling regulation}

Interestingly, TNC and HEY1 are commonly trans-activated by Notch and TGF $\beta$ signaling [71,100,101]. In fact, Notch is also upregulated by sex determining region Y box 2 (SOX2), SOX2 by SOX4, and SOX4 by TGF $\beta[93,102,103]$, while JAG1 is upregulated by TGF $\beta$ and Wnt [104,105]. This shows the different levels through which Notch, TGF $\beta$ and Wnt pathways act in a concerted and synergistic manner.

\section{Clinical studies using Notch inhibitors}

Notch signaling has emerged as a specific therapeutic target for T-ALL [50] and colon cancer [106], as well as a potential target against tumor angiogenesis $[105,107,108]$. Blocking of Notch pathway induces apoptosis and depletes cancer stem cells in medulloblastoma [109]. A phase I study of GSI MK0752 for adult and pediatric patients with relapsed or refractory acute t-cell lymphoblastic leukemia and lymphoma is ongoing (NCT00100152). More recently, a phase I study of MK0752 was initiated in patients with metastatic or locally advanced breast cancer and other solid tumors (NCT00106145). A new clinical trial has just started for treating patients with recurrent or progressive GBM using GSI RO4929097 (NCT01122901) http://clinicaltrials. gov/ct2/show/NCT01122901?term=notch\&rank=14.

The difficulty of distinguishing Notch1 and Notch2 specific activities from one another in GBM modulating proliferation, angiogenesis, invasion and cancer stem cell maintenance suggests by default that both are mostly redundant. Indeed, the pharmacological approaches using GSI do not discriminate for a specific Notch receptor and cause gastrointestinal toxicity as side effect [106]. However, based on the specific role of Dll4Notch1 in neovascularization, anti-Dll4, and similarly anti-Notch1 and anti-Notch2 antibodies have been proposed as sharper therapeutic agents devoid of side effects against various tumor types in mouse xenograft models $[107,110]$. The use of mouse glioma models put into specific Notch mutant backgrounds may help to solve this issue. Further downstream, the role of noncanonical Notch pathway has not been clarified yet and more in-depth studies will be needed to define the effect on Notch canonical pathway.

\section{Concluding remarks and discussion}

GBM is the most prevalent and the most aggressive brain tumor against which conventional therapies, that is, radiotherapy, chemotherapy and surgery have led until now to only transient clinical response followed by tumor recurrence, with no significant improvement of patient survival. Notch signaling has recently been identified to cumulate oncogenic activities in GBM proliferation, apoptosis inhibition and invasion. Additional functions in maintaining non-neoplastic neural stem cells and in neovascularization and in EMT switch of other malignancies remain to be demonstrated in GBM. With the development of novel therapies interfering with identified cancer pathways, Notch pathway therefore holds a promise of being a particularly appropriate target to fight against GBM.

Prerequisites need to be fulfilled by a compound potentially designed for targeted GBM therapy. The drug needs to be harmless for healthy cells and to be able to pass the blood brain barrier to penetrate the tumor. Further, as previously shown in vitro [111,112], combinations of compounds that target non-redundant GBM pathways or with cytotoxic agents may synergize to induce GBM cell death. Such combinations that would include Notch signaling inhibitors are hoped will provide promising therapies to substantially improve patient outcomes. 


\section{Acknowledgements}

This work was supported by Oncosuisse (01338; OCS-01613-12-2004), Regional Cancer League of Basel-Stadt and Baselland (No. 7-2004)

\section{Author details}

'Laboratory of Molecular Neuro-Oncology, Department of Biomedicine, University Hospital Basel, Basel, Switzerland. '2Laboratory of Brain Tumor Biology, Department of Biomedicine, University Hospital Basel, Basel, Switzerland.

\section{Authors' contributions}

$M L$ and JL Boulay assisted in the review conceptualization, design and writing of the manuscript. AM assisted with the review and in writing the manuscript.

\section{Competing interests}

The authors declare that they have no competing interests.

Received: 12 July 2010 Accepted: 15 November 2010

Published: 15 November 2010

\section{References}

1. Zhu Y, Parada LF: The molecular and genetic basis of neurological tumours. Nat Rev Cancer 2002, 2:616-626.

2. Ohgaki $H$, Kleihues P: Population-based studies on incidence, survival rates, and genetic alterations in astrocytic and oligodendroglial gliomas. J Neuropathol Exp Neurol 2005, 64:479-489.

3. Newton HB: Primary brain tumors: review of etiology, diagnosis and treatment. Am Fam Physician 1994, 49:787-797.

4. Newton HB: Molecular neuro-oncology and development of targeted therapeutic strategies for brain tumors. Part 2: PI3K/Akt/PTEN, mTOR, SHH/PTCH and angiogenesis. Expert Rev Anticancer Ther 2004, 4:105-128.

5. Ohgaki H, Dessen P, Jourde B, Horstmann S, Nishikawa T, Di Patre PL, Burkhard C, Schuler D, Probst-Hensch NM, Maiorka PC, Baeza N, Pisani P, Yonekawa $Y$, Yasargil MG, Lütolf UM, Kleihues P: Genetic pathways to glioblastoma: a population-based study. Cancer Res 2004, 64:6892-6899.

6. Parsons DW, Jones S, Zhang X, Lin JC, Leary RJ, Angenendt P, Mankoo P, Carter H, Siu IM, Gallia GL, Olivi A, McLendon R, Rasheed BA, Keir S, Nikolskaya T, Nikolsky Y, Busam DA, Tekleab H, Diaz LA Jr, Hartigan J, Smith DR, Strausberg RL, Marie SK, Shinjo SM, Yan H, Riggins GJ, Bigner DD, Karchin R, Papadopoulos N, Parmigiani G, Vogelstein B, Velculescu VE, Kinzler KW: An integrated genomic analysis of human glioblastoma multiforme. Science 2008, 321:1807-12.

7. Cancer Genome Atlas Research Network: Comprehensive genomic characterization defines human glioblastoma genes and core pathways. Nature 2008, 455:1061-1068.

8. Poulson DF: Chromosomal deficiencies and the embryonic development of Drosophila melanogaster. Proc Natl Acad Sci USA 1937, 23:133-137.

9. Rebay I, Fehon RG, Artavanis-Tsakonas S: Specific truncations of Drosophila Notch define dominant activated and dominant negative forms of the receptor. Cell 1993, 74:319-329.

10. Brennan K, Tateson R, Lewis K, Arias AM: A functional analysis of Notch mutations in Drosophila. Genetics 1997, 147:177-188.

11. Heitzler $P$, Simpson P: The choice of cell fate in the epidermis of Drosophila. Cell 1991, 64:1083-1092.

12. Artavanis-Tsakonas S, Muskavitch MA, Yedvobnick B: Molecular cloning of Notch, a locus affecting neurogenesis in Drosophila melanogaster. Proc Natl Acad Sci USA 1983, 80:1977-1981.

13. Blaumueller CM, Qi H, Zagouras P, Artavanis-Tsakonas S: Intracellular cleavage of Notch leads to a heterodimeric receptor on the plasma membrane. Cell 1997, 90:281-291.

14. Logeat F, Bessia C, Brou C, LeBail O, Jarriault S, Seidah NG, Israel A: The Notch1 receptor is cleaved constitutively by a furin-like convertase. Proc Natl Acad Sci USA 1998, 95:8108-8112.

15. Weinmaster G, Roberts VJ, Lemke G: A homolog of Drosophila Notch expressed during mammalian development. Development (Cambridge, England) 1991, 113:199-205.

16. Weinmaster G, Roberts VJ, Lemke G: Notch2: a second mammalian Notch gene. Development (Cambridge, England) 1992, 116:931-941.
17. Lardelli M, Dahlstrand J, Lendahl U: The novel Notch homologue mouse Notch 3 lacks specific epidermal growth factor-repeats and is expressed in proliferating neuroepithelium. Mech Dev 1994, 46:123-136.

18. Uyttendaele H, Marazzi G, Wu G, Yan Q, Sassoon D, Kitajewski J: Notch4/int3 , a mammary proto-oncogene, is an endothelial cell-specific mammalian Notch gene. Development (Cambridge, England) 1996, 122:2251-2259

19. Higuchi M, Kiyama H, Hayakawa T, Hamada Y, Tsujimoto Y: Differential expression of Notch1 and Notch2 in developing and adult mouse brain. Brain Res 1995, 29:263-272.

20. Irvin DK, Zurcher SD, Nguyen T, Weinmaster G, Kornblum HI: Expression patterns of Notch1, Notch2, and Notch3 suggest multiple functional roles for the Notch-DSL signaling system during brain development. J Comp Neurol 2001, 436:167-181.

21. Tanaka M, Kadokawa Y, Hamada Y, Marunouchi T: Notch2 expression negatively correlates with glial differentiation in the postnatal mouse brain. J Neurobiol 1999, 41:524-539.

22. Morrison SJ, Perez SE, Qiao Z, Verdi JM, Hicks C, Weinmaster G, Anderson DJ: Transient Notch activation initiates an irreversible switch from neurogenesis to gliogenesis by neural crest stem cells. Cell 2000, 101:499-510

23. Solecki DJ, Liu XL, Tomoda T, Fang Y, Hatten ME: Activated Notch2 signaling inhibits differentiation of cerebellar granule neuron precursors by maintaining proliferation. Neuron 2001, 31:557-568.

24. Hitoshi S, Alexson T, Tropepe V, Donoviel D, Elia AJ, Nye JS, Conlon RA, Mak TW, Bernstein A, van der Kooy D: Notch pathway molecules are essential for the maintenance, but not the generation, of mammalian neural stem cells. Genes Dev 2002, 16:846-858.

25. Nagao M, Sugimori M, Nakafuku M: Cross talk between notch and growth factor/cytokine signaling pathways in neural stem cells. Mol Cell Biol 2007, 27:3982-3994.

26. Shimizu T, Kagawa T, Inoue T, Nonaka A, Takada S, Aburatani H, Taga T: Stabilized beta-catenin functions through TCF/LEF proteins and the Notch/RBP-Jk complex to promote proliferation and suppress differentiation of neural precursor cells. Mol Cell Biol 2008, 28:7427-7441.

27. Artavanis-Tsakonas $S$, Rand MD, Lake RJ: Notch signaling: cell fate control and signal integration in development. Science 1999, 284:770-776.

28. Schmidt M, Fan Z: Protection against chemotherapy-induced cytotoxicity by cyclin-dependent kinase inhibitors (CKI) in CKI-responsive cells compared with CKI-unresponsive cells. Oncogene 2001, 20:6164-6171.

29. Artavanis-Tsakonas S, Matsuno K, Fortini ME: Notch signaling. Science 1995, 268:225-232

30. Jarriault S, Brou C, Logeat F, Schroeter EH, Kopan R, Israel A: Signalling downstream of activated mammalian Notch. Nature 1995, 377:355-358

31. Mumm JS, Schroeter EH, Saxena MT, Griesemer A, Tian X, Pan DJ, Ray WJ, Kopan R: A ligand-induced extracellular cleavage regulates gammasecretase-like proteolytic activation of Notch1. Mol Cell 2000, 5:197-206.

32. Ramain P, Khechumian K, Seugnet L, Arbogast N, Ackermann C, Heitzler P Novel Notch alleles reveal a Deltex-dependent pathway repressing neural fate. Curr Biol 2001, 11:1729-1738.

33. Matsuno K, Eastman D, Mitsiades T, Quinn AM, Carcanciu ML, Ordentlich P, Kadesch T, Artavanis-Tsakonas S: Human deltex is a conserved regulator of Notch signalling. Nat Genet 1998, 19:74-78

34. Amsen D, Blander JM, Lee GR, Tanigaki K, Honjo T, Flavell RA: Instruction of distinct CD4 T helper cell fates by different notch ligands on antigenpresenting cells. Cell 2004, 117:515-526.

35. Kamakura S, Oishi K, Yoshimatsu T, Nakafuku M, Masuyama N, Gotoh Y: Hes binding to STAT3 mediates crosstalk between Notch and JAK-STAT signalling. Nat Cell Biol 2004, 6:547-554.

36. Sengupta A, Banerjee D, Chandra S, Banerji SK, Ghosh R, Roy R, Banerjee S: Deregulation and cross talk among Sonic hedgehog, Wnt, Hox and Notch signaling in chronic myeloid leukemia progression. Leukemia 2007, 21:949-955.

37. Ingram WJ, McCue KI, Tran TH, Hallahan AR, Wainwright BJ: Sonic Hedgehog regulates Hes 1 through a novel mechanism that is independent of canonical Notch pathway signalling. Oncogene 2008, 27:1489-1500

38. Hansson EM, Lendahl U, Chapman G: Notch signaling in development and disease. Semin Cancer Biol 2004, 14:320-328. 
39. Garg V, Muth AN, Ransom JF, Schluterman MK, Barnes R, King IN, Grossfeld PD, Srivastava D: Mutations in NOTCH1 cause aortic valve disease. Nature 2005, 437:270-274.

40. McDaniell R, Warthen DM, Sanchez-Lara PA, Pai A, Krantz ID, Piccoli DA, Spinner NB: NOTCH2 mutations cause Alagille syndrome, a heterogeneous disorder of the notch signaling pathway. Am J Hum Genet 2006, 79:169-173.

41. Joutel A, Corpechot C, Ducros A, Vahedi K, Chabriat H, Mouton P, Alamowitch S, Domenga V, Cecillion M, Marechal E, Maciazek J, Vayssiere C, Cruaud C, Cabanis EA, Ruchoux MM, Weissenbach J, Bach JF, Bousser MG, Tournier-Lasserve E: Notch3 mutations in CADASIL, a hereditary adultonset condition causing stroke and dementia. Nature 1996, 383:707-710.

42. Wei J, Hemmings GP: The NOTCH4 locus is associated with susceptibility to schizophrenia. Nat Genet 2000, 25:376-377.

43. Limbourg FP, Takeshita K, Radtke F, Bronson RT, Chin MT, Liao JK: Essential role of endothelial Notch1 in angiogenesis. Circulation 2005, 111:1826-1832.

44. Takeshita K, Satoh M, Ii M, Silver M, Limbourg FP, Mukai Y, Rikitake Y, Radtke F, Gridley T, Losordo DW, Liao JK: Critical role of endothelial Notch1 signaling in postnatal angiogenesis. Circ Res 2007, 100:70-78.

45. Krebs $L T$, Xue $Y$, Norton CR, Shutter JR, Maguire M, Sundberg JP, Gallahan D, Closson V, Kitajewski J, Callahan R, Smith GH, Stark KL, Gridley T: Notch signaling is essential for vascular morphogenesis in mice. Genes Dev 2000, 14:1343-1352.

46. Krebs $L T$, Xue $Y$, Norton $C R$, Sundberg JP, Beatus $P$, Lendahl $U$, Joutel $A$ Gridley T: Characterization of Notch3-deficient mice: normal embryonic development and absence of genetic interactions with a Notch1 mutation. Genesis 2003, 37:139-143.

47. Gale NW, Dominguez MG, Noguera I, Pan L, Hughes V, Valenzuela DM, Murphy AJ, Adams NC, Lin HC, Holash J, Thurston G, Yancopoulos GD: Haploinsufficiency of delta-like 4 ligand results in embryonic lethality due to major defects in arterial and vascular development. Proc Natl Acad Sci USA 2004, 101:15949-15954.

48. Bray SJ: Notch signalling: a simple pathway becomes complex. Nat Rev Mol Cell Biol 2006, 7:678-689.

49. Ellisen LW, Bird J, West DC, Soreng AL, Reynolds TC, Smith SD, Sklar J: TAN1 , the human homolog of the Drosophila notch gene, is broken by chromosomal translocations in T lymphoblastic neoplasms. Cell 1991, 66:649-661.

50. Weng AP, Ferrando AA, Lee W, Morris JPt, Silverman LB, Sanchez-lrizarry C, Blacklow SC, Look AT, Aster JC: Activating mutations of NOTCH1 in human T cell acute lymphoblastic leukemia. Science 2004, 306:269-271.

51. Lee SY, Kumano K, Nakazaki K, Sanada M, Matsumoto A, Yamamoto G, Nannya Y, Suzuki R, Ota S, Ota Y, Izutsu K, Sakata-Yanagimoto M, Hangaishi A, Yagita H, Fukayama M, Seto M, Kurokawa M, Ogawa S, Chiba S: Gain-of-function mutations and copy number increases of Notch2 in diffuse large B-cell lymphoma. Cancer Sci 2009, 100:920-926.

52. Radtke F, Raj $\mathrm{K}$ : The role of Notch in tumorigenesis: oncogene or tumour suppressor? Nat Rev Cancer 2003, 3:756-767.

53. Guentchev M, McKay RD: Notch controls proliferation and differentiation of stem cells in a dose-dependent manner. Eur J Neurosci 2006, 23:2289-2296.

54. Boulay JL, Miserez AR, Zweifel C, Sivasankaran B, Kana V, Ghaffari A, Luyken C, Sabel M, Zerrouqi A, Wasner M, Van Meir E, Tolnay M, Reifenberger G, Merlo A: Loss of NOTCH2 positively predicts survival in subgroups of human glial brain tumors. PLOS ONE 2007, 2:e576.

55. Sivasankaran B, Degen M, Ghaffari A, Hegi ME, Hamou MF, lonescu MC, Zweifel C, Tolnay M, Wasner M, Mergenthaler S, Miserez AR, Kiss R, Lino MM, Merlo A, Chiquet-Ehrismann R, Boulay JL: Tenascin-C is a novel RBPJk-induced target gene for Notch signaling in gliomas. Cancer Res 2009, 69:458-465.

56. Purow BW, Haque RM, Noel MW, Su Q, Burdick MJ, Lee J, Sundaresan T, Pastorino S, Park JK, Mikolaenko I, Maric D, Eberhart CG, Fine HA: Expression of Notch-1 and its ligands, Delta-like- 1 and Jagged-1, is critical for glioma cell survival and proliferation. Cancer Res 2005, 65:2353-2363

57. Leong KG, Niessen K, Kulic I, Raouf A, Eaves C, Pollet I, Karsan A: Jagged1mediated Notch activation induces epithelial-to-mesenchymal transition through slug-induced repression of E-cadherin. J Exp Med 2007, 204:2935-2948.
58. Sahlgren C, Gustafsson MV, Jin S, Poellinger L, Lendahl U: Notch signaling mediates hypoxia-induced tumor cell migration and invasion. Proc Natl Acad Sci USA 2008, 105:6392-6397.

59. Lino M, Merlo A: Translating biology into clinic: the case of glioblastoma. Curr Opin Cell Biol 2009, 21:311-316.

60. Dang L, Fan X, Chaudhry A, Wang M, Gaiano N, Eberhart CG: Notch3 signaling initiates choroid plexus tumor formation. Oncogene 2006, 25:487-491.

61. Fan X, Mikolaenko I, Elhassan I, Ni X, Wang Y, Ball D, Brat DJ, Perry A, Eberhart CG: Notch1 and notch2 have opposite effects on embryonal brain tumor growth. Cancer Res 2004, 64:7787-7793.

62. Purow BW, Sundaresan TK, Burdick MJ, Kefas BA, Comeau LD, Hawkinson MP, Su Q, Kotliarov Y, Lee J, Zhang W, Fine HA: Notch-1 regulates transcription of the epidermal growth factor receptor through p53. Carcinogenesis 2008, 29:918-925.

63. Brennan C, Momota H, Hambardzumyan D, Ozawa T, Tandon A, Pedraza A, Holland E: Glioblastoma subclasses can be defined by activity among signal transduction pathways and associated genomic alterations. PLOS ONE 2009, 4:e7752.

64. Libermann TA, Nusbaum HR, Razon N, Kris R, Lax I, Soreq H, Whittle N, Waterfield MD, Ullrich A, Schlessinger J: Amplification, enhanced expression and possible rearrangement of EGF receptor gene in primary human brain tumours of glial origin. Nature 1985, 313:144-147.

65. Libermann TA, Nusbaum HR, Razon N, Kris R, Lax I, Soreq H, Whittle N, Waterfield MD, Ullrich A, Schlessinger J: Amplification and overexpression of the EGF receptor gene in primary human glioblastomas. J Cell Sci Supp/ 1985, 3:161-172.

66. Merlo A: Genes and pathways driving glioblastomas in humans and murine disease models. Neurosurg Rev 2003, 26:145-158.

67. Ma J, Meng Y, Kwiatkowski DJ, Chen X, Peng H, Sun Q, Zha X, Wang F, Wang $Y$, Jing $Y$, Zhang $S$, Chen R, Wang L, Wu E, Cai G, MalinowskaKolodziej I, Liao Q, Liu Y, Zhao Y, Sun Q, Xu K, Dai J, Han J, Wu L, Zhao RC, Shen $\mathrm{H}$, Zhang $\mathrm{H}$ : Mammalian target of rapamycin regulates murine and human cell differentiation through STAT3/p63/Jagged/Notch cascade. J Clin Invest 2010, 120:103-114

68. Patten BA, Sardi SP, Koirala S, Nakafuku M, Corfas G: Notch1 signaling regulates radial glia differentiation through multiple transcriptional mechanisms. J Neurosci 2006, 26:3102-3108.

69. Fan QW, Cheng C, Knight ZA, Haas-Kogan D, Stokoe D, James CD, McCormick F, Shokat KM, Weiss WA: EGFR signals to mTOR through PKC and independently of Akt in glioma. Sci Signal 2009, 2:ra4.

70. Christofori G: New signals from the invasive front. Nature 2006, 441:444-450.

71. Zavadil J, Cermak L, Soto-Nieves N, Bottinger EP: Integration of TGF-beta/ Smad and Jagged1/Notch signalling in epithelial-to-mesenchymal transition. EMBO J 2004, 23:1155-1165.

72. Garcion E, Faissner A, ffrench-Constant C: Knockout mice reveal a contribution of the extracellular matrix molecule tenascin- $C$ to neural precursor proliferation and migration. Development (Cambridge, England) 2001, 128:2485-2496.

73. Gustafsson MV, Zheng X, Pereira T, Gradin K, Jin S, Lundkvist J, Ruas JL, Poellinger $L$, Lendahl $U$, Bondesson M: Hypoxia requires notch signaling to maintain the undifferentiated cell state. Dev Cell 2005, 9:617-628.

74. Nishio T, Kawaguchi S, Yamamoto M, Iseda T, Kawasaki T, Hase T: Tenascin$\mathrm{C}$ regulates proliferation and migration of cultured astrocytes in a scratch wound assay. Neuroscience 2005, 132:87-102.

75. Leins A, Riva P, Lindstedt R, Davidoff MS, Mehraein P, Weis S: Expression of tenascin- $C$ in various human brain tumors and its relevance for survival in patients with astrocytoma. Cancer 2003, 98:2430-2439.

76. Puget $S$, Grill J, Valent A, Bieche I, Dantas-Barbosa C, Kauffmann A, Dessen P, Lacroix L, Geoerger B, Job B, Dirven C, Varlet P, Peyre M, Dirks PB, Sainte-Rose C, Vassal G: Candidate genes on chromosome $9 q 33-34$ involved in the progression of childhood ependymomas. J Clin Oncol 2009, 27:1884-1892.

77. Reya T, Morrison SJ, Clarke MF, Weissman IL: Stem cells, cancer, and cancer stem cells. Nature 2001, 414:105-111.

78. Ailles LE, Weissman IL: Cancer stem cells in solid tumors. Curr Opin Biotechnol 2007, 18:460-466

79. Bonnet D, Dick JE: Human acute myeloid leukemia is organized as a hierarchy that originates from a primitive hematopoietic cell. Nat Med 1997, 3:730-737. 
80. Voog J, Jones DL: Stem cells and the niche: a dynamic duo. Cell Stem Cell 6:103-115.

81. Duncan AW, Rattis FM, DiMascio LN, Congdon KL, Pazianos G, Zhao C, Yoon K, Cook JM, Willert K, Gaiano N, Reya T: Integration of Notch and Wnt signaling in hematopoietic stem cell maintenance. Nat Immunol 2005, 6:314-322.

82. Kageyama R, Ohtsuka T, Hatakeyama J, Ohsawa R: Roles of bHLH genes in neural stem cell differentiation. Exp Cell Res 2005, 306:343-348.

83. Woodward WA, Chen MS, Behbod F, Rosen JM: On mammary stem cells. Cell Sci 2005, 118:3585-3594.

84. Fischer A, Gessler M: Delta-Notch-and then? Protein interactions and proposed modes of repression by Hes and Hey bHLH factors. Nucleic Acids Res 2007, 35:4583-4596.

85. Shih $\mathrm{AH}$, Holland EC: Notch signaling enhances nestin expression in gliomas. Neoplasia 2006, 8:1072-1082

86. Ge W, Martinowich K, Wu X, He F, Miyamoto A, Fan G, Weinmaster G, Sun YE: Notch signaling promotes astrogliogenesis via direct CSLmediated glial gene activation. J Neurosci Res 2002, 69:848-860.

87. Wu Y, Liu Y, Levine EM, Rao MS: Hes1 but not Hes5 regulates an astrocyte versus oligodendrocyte fate choice in glial restricted precursors. Dev Dyn 2003, 226:675-689.

88. Bartel DP: MicroRNAs: genomics, biogenesis, mechanism, and function. Cell 2004, 116:281-297.

89. Garzia L, Andolfo I, Cusanelli E, Marino N, Petrosino G, De Martino D, Esposito V, Galeone A, Navas L, Esposito S, Gargiulo S, Fattet S, Donofrio V, Cinalli G, Brunetti A, Vecchio LD, Northcott PA, Delattre O, Taylor MD, lolascon A, Zollo M: MicroRNA-199b-5p impairs cancer stem cells through negative regulation of HES1 in medulloblastoma. PLOS ONE 2009, 4:e4998.

90. Wang H, Lathia JD, Wu Q, Wang J, Li Z, Heddleston JM, Eyler CE, Elderbroom J, Gallagher J, Schuschu J, MacSwords J, Cao Y, McLendon RE, Wang XF, Hjelmeland AB, Rich JN: Targeting interleukin 6 signaling suppresses glioma stem cell survival and tumor growth. Stem Cells 2009, 27:2393-2404.

91. Seidel S, Garvalov BK, Wirta V, von Stechow L, Schanzer A, Meletis K, Wolter M, Sommerlad D, Henze AT, Nister M, Reifenberger G, Lundeberg J, Frisén J, Acker T: A hypoxic niche regulates glioblastoma stem cells through hypoxia inducible factor 2a. Brain 133:983-995.

92. Guessous F, Zhang Y, Kofman A, Catania A, Li Y, Schiff D, Purow B, Abounader R: microRNA-34a is tumor suppressive in brain tumors and glioma stem cells. Cell Cycle 2010, 9:1031-1036.

93. Bani-Yaghoub M, Tremblay RG, Lei JX, Zhang D, Zurakowski B, Sandhu JK Smith B, Ribecco-Lutkiewicz M, Kennedy J, Walker PR, Sikorska M: Role of Sox 2 in the development of the mouse neocortex. Dev Biol 2006, 295:52-66

94. Panchision DM: The role of oxygen in regulating neural stem cells in development and disease. J Cell Physiol 2009, 220:562-568.

95. Rehman $\mathrm{AO}$, Wang $\mathrm{CY}$ : Notch signaling in the regulation of tumor angiogenesis. Trends Cell Biol 2006, 16:293-300.

96. Reedijk M, Odorcic S, Chang L, Zhang H, Miller N, McCready DR, Lockwood G, Egan SE: High-level coexpression of JAG1 and NOTCH1 is observed in human breast cancer and is associated with poor overall survival. Cancer Res 2005, 65:8530-8537.

97. Santagata S, Demichelis F, Riva A, Varambally S, Hofer MD, Kutok JL, Kim R, Tang J, Montie JE, Chinnaiyan AM, Rubin MA, Aster JC: JAGGED1 expression is associated with prostate cancer metastasis and recurrence. Cancer Res 2004, 64:6854-6857.

98. Soares R, Balogh G, Guo S, Gartner F, Russo J, Schmitt F: Evidence for the notch signaling pathway on the role of estrogen in angiogenesis. $\mathrm{Mol}$ Endocrinol 2004, 18.2333-2343.

99. Patten BA, Peyrin JM, Weinmaster G, Corfas G: Sequential signaling through Notch1 and erbB receptors mediates radial glia differentiation. $J$ Neurosci 2003, 23:6132-6140.

100. Jinnin M, Ihn H, Asano Y, Yamane K, Trojanowska M, Tamaki K: Tenascin-C upregulation by transforming growth factor-beta in human dermal fibroblasts involves Smad3, Sp1, and Ets1. Oncogene 2004, 23:1656-1667.

101. Jinnin M, Ihn H, Asano Y, Yamane K, Trojanowska M, Tamaki K: Platelet derived growth factor induced tenascin- $C$ transcription is phosphoinositide 3-kinase/Akt-dependent and mediated by Ets family transcription factors. J Cell Physiol 2006, 206:718-727.

102. Ikushima H, Miyazono K: Cellular context-dependent "colors" of transforming growth factor-beta signaling. Cancer Sci 101:306-312
103. Ikushima H, Todo T, Ino Y, Takahashi M, Miyazawa K, Miyazono K: Autocrine TGF-beta signaling maintains tumorigenicity of glioma-initiating cells through Sry-related HMG-box factors. Cell Stem Cell 2009, 5:504-514.

104. Bruna A, Darken RS, Rojo F, Ocana A, Penuelas S, Arias A, Paris R, Tortosa A, Mora J, Baselga J, Seoane J: High TGF $\beta$-Smad activity confers poor prognosis in glioma patients and promotes cell proliferation depending on the methylation of the PDGF-B gene. Cancer Cell 2007, 11:147-160.

105. Noguera-Troise I, Daly C, Papadopoulos NJ, Coetzee S, Boland P, Gale NW, Lin HC, Yancopoulos GD, Thurston G: Blockade of Dll4 inhibits tumour growth by promoting non-productive angiogenesis. Nature 2006, 444:1032-1037.

106. van Es JH, van Gijn ME, Riccio O, van den Born M, Vooijs M, Begthel H, Cozijnsen M, Robine S, Winton DJ, Radtke F, Clevers H: Notch/gammasecretase inhibition turns proliferative cells in intestinal crypts and adenomas into goblet cells. Nature 2005, 435:959-963.

107. Ridgway J, Zhang G, Wu Y, Stawicki S, Liang WC, Chanthery Y, Kowalski J, Watts RJ, Callahan C, Kasman I, Singh M, Chien M, Tan C, Hongo JA, de Sauvage F, Plowman G, Yan M: Inhibition of Dll4 signalling inhibits tumour growth by deregulating angiogenesis. Nature 2006 444:1083-1087.

108. Kopan R, llagan MX: The canonical Notch signaling pathway: unfolding the activation mechanism. Cell 2009, 137:216-233.

109. Fan X, Matsui W, Khaki L, Stearns D, Chun J, Li YM, Eberhart CG: Notch pathway inhibition depletes stem-like cells and blocks engraftment in embryonal brain tumors. Cancer Res 2006, 66:7445-7452.

110. Wu G, Mambo E, Guo Z, Hu S, Huang X, Gollin SM, Trink B, Ladenson PW, Sidransky D, Xing M: Uncommon mutation, but common amplifications, of the PIK3CA gene in thyroid tumors. J Clin Endocrinol Metab 2005, 90:4688-4693.

111. Failly M, Korur S, Egler V, Boulay JL, Lino MM, Imber R, Merlo A: Combination of sublethal concentrations of epidermal growth factor receptor inhibitor and microtubule stabilizer induces apoptosis of glioblastoma cells. Mol Cancer Ther 2007, 6:773-781.

112. Egler V, Korur S, Failly M, Boulay JL, Imber R, Lino MM, Merlo A: Histone deacetylase inhibition and blockade of the glycolytic pathway synergistically induce glioblastoma cell death. Clin Cancer Res 2008, 14:3132-3140.

\section{Pre-publication history}

The pre-publication history for this paper can be accessed here: http://www.biomedcentral.com/1741-7015/8/72/prepub

doi:10.1186/1741-7015-8-72

Cite this article as: Lino et al: Notch signaling in glioblastoma: a developmental drug target?. BMC Medicine 2010 8:72.

\section{Submit your next manuscript to BioMed Central and take full advantage of:}

- Convenient online submission

- Thorough peer review

- No space constraints or color figure charges

- Immediate publication on acceptance

- Inclusion in PubMed, CAS, Scopus and Google Scholar

- Research which is freely available for redistribution
Biomed Central 